\title{
Cytomegalovirus and blood transfusion in neonates
}

\author{
J. W. T. BENSON, S. J. BODDEN, AND J. O'H. TOBIN
}

Department of Paediatrics, John Radcliffe Hospital, and Virus Laboratory, Churchill Hospital, Oxford

SUMMARY A fatal case of neonatal cytomegalovirus (CMV) infection attributed to exchange transfusion is described. The incidence of CMV transmission by exchange and other neonatal transfusion was studied, and the use of CMV antibody-free blood for these procedures was shown to be effective in preventing CMV infection in neonates.

Cytomegalovirus infection is a well recognised complication of blood transfusion, leading in some cases to the post-transfusion syndrome. Recent studies have shown that about $25 \%$ of exchange transfused neonates become infected with cytomegalovirus (CMV), and although transfusion-acquired CMV infection in infants seldom causes obvious illness, it may do (Yeager, 1974; Tobin et al., 1975; Pass et al., 1976).

An infant born in Oxford apparently died from CMV infection after transfusion. We describe this fatal case and report the results of our studies into the effectiveness of CMV antibody-free blood in avoiding transfusion-acquired infection.

\section{Patients and methods}

Between April 1975 and October 1976, 80 surviving babies were transfused in the special care unit at the John Radcliffe Hospital; 64 of them were followed up. 18 received exchange transfusions of between 200 and $1500 \mathrm{ml}$ blood (mean $550 \mathrm{ml}$ ). The blood used was less than 4 days old and preserved in acid-citrate-dextrose. 46 received simple transfusions of between 5 and $150 \mathrm{ml}$ (mean $30 \mathrm{ml}$ ). Initially blood for simple transfusions was obtained from 'walking donors' who were staff members of the special care or maternity units. The blood was taken into a sterile heparinised syringe and given straight to the baby. During the last 6 months of the study most simple transfusions were of CMV antibodyfree blood from the Oxford Regional Transfusion Service supplied in $50 \mathrm{ml}$ minipacks (Gunson et al., in preparation), between one and 7 days old.

42 babies were studied retrospectively and 22

\footnotetext{
Alder Hey Children's Hospital, Liverpool

J. W. T. BENSON, senior paediatric registrar

Institute of Child Health, Birmingham

S. J. BODDEN, senior research fellow

Churchill Hospital, Oxford

J. о’H. тOBIN, consultant virologist
}

prospectively. The retrospective group were seen at least once between ages 10 weeks and 14 months, at which time the babies were physically examined and their development, head circumferences, and hearing were assessed. Blood for CMV complementfixation tests and immunofluorescent antibody (de Silva et al., 1977) was taken from both mother and baby, and a throat swab and urine were taken from the baby for virus isolation on human embryo fibroblast cultures. In the prospective group blood was taken from the mother within 2 weeks after transfusion of the baby, and a throat swab and urine were collected from the baby for virus culture within 3 days of transfusion. The mothers and babies in this group were seen again between 3 and 6 months after transfusion, and 8 of them were seen a second time at between 6 and 9 months; at these times the baby was clinically assessed and a throat swab, urine, and blood were taken for virus investigation as in the retrospective group.

All the 42 babies studied retrospectively received blood from donors who had not been screened for CMV antibody, although subsequently the CMV antibody titres of all blood donors were determined for 33 of the babies. For the remaining 9 babies the CMV titre of at least one donor could not be ascertained. In the prospective group of 22 babies one or more donors for 3 babies were not available for CMV serological tests. 16 babies were given CMV antibody-free blood deliberately.

97 infants aged between 5 and 18 months, who had not been transfused and who were attending an infant welfare clinic, or were in hospital, served as controls; they were tested for CMV infection either by virus isolation or serology.

\section{Results}

In the first 13 months of the study, before a policy of selection of CMV-negative donors was introduced, 
Table $1 C M V$ infection after neonatal blood transfusion

\begin{tabular}{|c|c|c|c|c|c|c|}
\hline Study & $\begin{array}{l}\text { Type of } \\
\text { transfusion }\end{array}$ & $\begin{array}{l}\text { No. } \\
\text { tested }\end{array}$ & $\begin{array}{l}\text { No. } \\
\text { infected }\end{array}$ & $\begin{array}{l}\text { Virus } \\
\text { isolation }\end{array}$ & $\begin{array}{l}\text { Antibody } \\
\text { production }\end{array}$ & Infected $(\%)$ \\
\hline $\begin{array}{l}\text { Retrospective } \\
\text { 'Untested blood' }\end{array}$ & $\begin{array}{l}\text { Exchange } \\
\text { 'Top up' }\end{array}$ & 16 & 4 & 3 & 4 & 25 \\
\hline Prospective & Exchange & 2 & 0 & 0 & 0 & 0 \\
\hline CMV-free blood & 'Top up' & 14 & 0 & $\mathbf{0}$ & 0 & 0 \\
\hline & $\int_{(5-12 \text { months })}^{\text {Infants }}$ & 42 & 2 & 2 & NT & $4 \cdot 8$ \\
\hline Controls, not transfused & $\left\{\begin{array}{l}\text { Infants } \\
\text { (5-18 months) }\end{array}\right.$ & 55 & 2 & NT & 2 & $3 \cdot 6$ \\
\hline
\end{tabular}

$4(25 \%)$ of 16 exchange transfused babies and 4 $(12.5 \%)$ of 32 receiving simple transfusions became infected with CMV. During the last 5 months of the study, the 2 babies exchange transfused and all 14 receiving simple transfusions of CMV antibodyfree blood remained uninfected (Table 1).

The blood donor CMV status was determined by immunofluorescence (IF) (de Silva et al., 1977) for 52 of the 64 babies. 21 babies received blood from at least one CMV antibody-positive donor and 8 (38\%) became infected, while the 31 babies who received only CMV antibody-free blood remained uninfected. Comparing these two groups by the $\chi^{2}$ test the result was significant $\left(\chi^{2}=11 \cdot 54\right.$, $\mathbf{P}<0.001)$. None of the 12 remaining babies who received blood from a donor of unknown CMV status became infected. The CMV infection rate by donor antibody status in those exchange transfused is given in Table 2 .

Exchange transfusions. The 4 babies who became infected after exchange transfusions received on average $864 \mathrm{ml}$ blood from 4 donors for each baby, compared with an average of $480 \mathrm{ml}$ from 2 donors for those 14 uninfected. Three of the 4 babies infected after exchange transfusion showed no clinical signs attributable to CMV during the period of observation. The 4th, who subsequently died, is described below.

\section{Case report}

A 33-year-old group $O$ Rhesus-negative mother who had previously had 3 liveborn babies and one stillborn baby affected by rhesus iso-immunisation,

Table $2 C M V$ infection in exchange transfusions according to donor antibody status

\begin{tabular}{lllc}
\hline $\begin{array}{l}\text { CMV antibody } \\
\text { status of donors }\end{array}$ & $\begin{array}{l}\text { No. of babies } \\
\text { tested }\end{array}$ & \multicolumn{2}{c}{ Infected babies } \\
\cline { 2 - 4 } & 7 & No. & $\%$ \\
\hline+ & 4 & 3 \\
UK* $^{*}$ & 7 & 1 & 36 \\
\hline
\end{tabular}

*Unknown. became pregnant again with a rising $\mathrm{Rh}$ antibody titre during the 2 nd trimester. She refused intrauterine transfusion and underwent plasmapheresis, a total of 50 units of plasma being exchanged over 10 weeks. The $R h$ antibody level remained fairly steady and she was delivered by caesarean section at 30 weeks' gestation. She had received a 40 -hour course of betamethasone since an amniocentesis 3 days before delivery had shown the amniotic fluid palmitate to be $19 \mathrm{mmol} / \mathrm{l}$. Her baby daughter weighed $1300 \mathrm{~g}$ at birth and had an enlarged liver and spleen, but was not hydropic. The baby's blood group was $\mathrm{O} R \mathrm{R}$ positive, her cord plasma bilirubin was $100 \mu \mathrm{mol} / 1(6 \mathrm{mg} / 100 \mathrm{ml})$, haemoglobin $7 \cdot 3 \mathrm{~g} / \mathrm{dl}$, reticulocytes $30 \%$, and the direct Coombs's test strongly positive. She was given 4 exchange transfusions during the next 2 days through an umbilical venous catheter with 0-2-day old, partially packed ACD blood. Phototherapy was given for the first 3 days of life and the bilirubin level had fallen to 70 $\mu \mathrm{mol} / 1(4 \mathrm{mg} / 100 \mathrm{ml})$ by day 6 . Twelve hours after the last exchange transfusion she was given $5 \mathrm{ml}$ platelet concentrate and $30 \mathrm{ml}$ fresh heparinised blood as she had rectal bleeding and a platelet count of $39 \times 10^{9} / 1$. Feeds of expressed breast milk were gradually introduced 5 days after the onset of the rectal bleeding, and although she required IV alimentation for 9 days, she apparently made a complete recovery from her haemolytic disease by the 12th day of life.

Six days later she became mottled and less active and her temperature became unstable. She was treated with gentamicin, cloxacillin, and carbenicillin, although bacteriological reports subsequently showed no pathogens. The antibiotics were changed to chloramphenicol and penicillin when her condition did not improve. Her white blood count rose to $45.3 \times 10^{9} / 1$ on the 24 th day of life, with $15.4 \times 10^{9} / 1$ neutrophils, $18 \cdot 1 \times 10^{9} / 1$ lymphocytes, and $10 \cdot 8 \times$ $10^{9} / 1$ eosinophils.

On the 27th day she was noted to be jaundiced and her liver and spleen again became enlarged. Her total bilirubin rose to $425 \mu \mathrm{mol} / 1(25 \mathrm{mg} / 100 \mathrm{ml})$ with $200 \mu \mathrm{mol} / 1(11.5 \mathrm{mg} / 100 \mathrm{ml})$ conjugated. Her 
aspartate transaminase was $970 \mathrm{IU} / \mathrm{l}$, lactate dehydrogenase $3900 \mathrm{IU} / \mathrm{l}$, and alkaline phosphatase $165 \mathrm{IU} / \mathrm{l}$. Hepatitis B antigen was not detected, but CMV was isolated from urine and a throat swab taken at 23 days of age, and from CSF taken 8 days later. Her condition steadily deteriorated. She developed gross ascites and anaemia, her plasma sodium level fell, and she became hypoalbuminaemic. Her platelet count fell and she developed haematuria and a petechial rash. She became oliguric and despite treatment with albumin, blood transfusions, frusemide, and physiological doses of hydrocortisone, she died at age 28 days. Permission for necropsy was not obtained.

The mother's blood taken at 20 weeks' gestation and at delivery contained CMV IgG antibodies at a titre of $1: 64$ but no specific CMV IgM or IgA was detected in either specimen. The baby's cord blood total IgM was $<25 \mathrm{mg} / 100 \mathrm{ml}(<30 \mathrm{IU} / \mathrm{ml})$ but none was available for testing for specific CMV antibodies. Three of the 4 blood donors for the exchange transfusions were found retrospectively to be CMV antibody positive. The donor of a small blood transfusion given on day 5 was also CMV positive. The CMV antibody status of the platelet donation was not determined.

Simple transfusions. The 4 babies who became infected after simple transfusions showed no clinical signs of infection. At follow-up between 5 and 13 months of age, 3 were still excreting virus and all had antibody to CMV. Three were normal on examination. The 4th was mildly retarded, probably as a result of repeated severe apnoeic attacks after delivery at 28 weeks' gestation.

Maternal CMV infection. Sera from 6 of the 8 mothers of infected babies were available for testing from late pregnancy and again when the babies were seen for follow-up. Five of these mothers had antibody to CMV before delivery, 4 of whom showed no change in titre. One showed a 16-fold rise in complement-fixation titre from $1: 8$ to $1: 96$ at 8 months after delivery, indicating reinfection or reactivation of her previous CMV infection. The 6th mother who had no CMV antibody before delivery showed a raised titre $(1: 32)$ when tested 5 months postpartum.

\section{Discussion}

Although cytomegalovirus infection after blood transfusions usually produces no clinical disease, in a few patients it can produce post-transfusion mononucleosis (Foster and Jack, 1969), and this syndrome can occur at any age including the first few weeks of life (Tobin et al., 1975). Cytomegalovirus infection can however be accentuated by immunosuppression, especially in patients undergoing renal and other transplants in whom primary infections can cause worrying symptoms and may occasionally lead to a fatal outcome. It is also an occasional complication in leukaemic and lupus patients and in others on immunosuppressive treatment.

It cannot be absolutely certain that the fatal case reported here acquired CMV infection from blood transfusion. However, there was no serological or other laboratory or clinical evidence that this was a congenital infection; the mother had neither IgA nor IgM CMV antibodies at any time during pregnancy and the isolation of virus from urine, throat swabs, and CSF during the illness would indicate a generalised viraemia in the baby.

Although the neonate usually does not seem to be any more likely to produce overt symptoms after CMV infection from transfusion than older people, such babies may be a danger to their mothers who usually are infected by them during the ensuing months. If these mothers happen to be pregnant and nonimmune, it is possible that the fetus could be affected by cytomegalic inclusion disease. As the usefulness of transfusion with CMV-free blood is still open to discussion, evidence on the effectiveness of screening blood for CMV antibody, and the demonstration that infection can be so prevented by its use are worth while.

For CMV antibody determination we used the IF antibody test (de Silva et al., 1977) as it is more sensitive than the complement-fixation (CF) test and quicker to perform, a result being obtained in 2 hours as opposed to the overnight incubation required for the CF test. Our results using this IF test in exchange transfused babies indicates that it is satisfactory for blood screening. Although the numbers are not great, the difference between those infected after receiving CMV-positive blood and those not infected after negative blood was significant.

It is obvious that all blood cannot be screened for CMV antibodies by all blood transfusion centres, but we feel that there should be more studies to see if the use of CMV-negative blood in exchange transfusions of babies is worth while. These should be parallel to studies in patients undergoing transplants and heart operations where CMV infection in the nonimmune can be prevented by screening blood and kidney donors and using material only from those without CMV antibody.

We thank Miss Eileen Hopkins and her staff at the East Oxford Health Centre for specimens from infants; Dr G. R. H. Gunson, Oxford Regional 
Blood Transfusion Service, for samples from blood donors; Dr D. Knight for help with the case history; and Professor J. P. M. Tizard and Dr J. D. Baum for encouragement and advice.

\section{References}

de Silva, L. M., Kampfner, F. L., Lister, C. M., and Tobin, J. O'H. (1977). Identification of pregnancies at risk from cytomegalovirus infection. Journal of Hygiene, 79, 347-354.

Foster, K. M., and Jack, I. (1969). A prospective study of the role of cytomegalovirus in post-transfusion mononucleosis. New England Journal of Medicine, 280, 1311-1316.

Pass, M. A., Johnson, J. D., Schulman, I. A., Grumet, C. F.,
Hafleigh, E. B., Malachowski, N. C., and Sunshine, P. (1976). Evaluation of a walking donor blood test transfusion program in an intensive care unit. Journal of Pediatrics, 89, 646-651.

Tobin, J. O'H., MacDonald, H., and Brayshay, M. (1975). Letter: Cytomegalovirus infection and exchange transfusion. British Medical Journal, 4, 404.

Yeager, A. S. (1974). Transfusion-acquired cytomegalovirus infection in newborn infants. American Journal of Diseases of Children, 128, 478-483.

Correspondence to Dr J. Benson, Alder Hey Children's Hospital, Eaton Road, Liverpool L12 2AP.

Received 12 September 1978

The following articles will appear in future issues of this Journal:

Role of viruses and bacteria in acute wheezy bronchitis in childhood: a study of sputum. M. E. C. Horn, S. E. Reed, and P. Taylor.

Pulmonary hypoplasia: lung weight and radial alveolar count as criteria of diagnosis. S. S. Askenazi and M. Perlman.

Intrathecal serotherapy in neonatal tetanus. A controlled trial. M. R. Sedaghatian.

Munchausen syndrome by proxy in twins. D. A. Lee.

Subacute sclerosing panencephalitis after drug-induced immunosuppression. J. B. S. Coulter, N. Balch, and P. V. Best.

Neonatal small left colon syndrome. $L$. Rangecroft. 